\title{
Microbiological evaluation of industrialized and artisanal Minas fresh cheese commercialized in the Federal District, Brazil
}

\author{
Letícia FERNANDES SILVA RODRIGUES ${ }^{1}$, Sabrina LUNARA SANTOS PAVELQUESI ${ }^{1}$, \\ Ana Carolina ALMEIDA DE OLIVEIRA FERREIRA ${ }^{1}$, Erika DA SILVA MONTEIRO ${ }^{1}$, \\ Calliandra Maria DE SOUZA SILVA ${ }^{1}$, Izabel Cristina RODRIGUES DA SILVA ${ }^{1}$, Daniela CASTILHO ORSI
}

\begin{abstract}
The aim of this study was to evaluate the microbiological quality of Minas fresh cheese commercialized in Federal District, Brazil. For this, 20 samples of industrialized cheeses were collected in supermarkets and 20 samples of artisanal cheeses were collected in public food markets. The analyzes performed were total count of bacteria, determination of coliforms, count of S. aureus and identification of Salmonella spp. (InvA gene) and S. aureus (SeC gene). The results showed that 26 samples (65\%) were unfit for consumption according to Brazilian legislation. For industrialized cheeses, 6 samples (15\%) of were unfit for consumption ( 3 samples for excess of thermotolerant coliforms and 3 samples for excess of S. aureus). For artisanal cheeses, all 20 samples (50\%) were unfit for consumption due to the high S. aureus counts, including 6 samples that had excess thermotolerant coliforms and 1 sample that was contaminated with Salmonella. Comparing the results, industrialized cheeses showed better microbiological quality than artisanal cheeses. Thus, artisanal Minas fresh cheeses commercialized in the public food markets of the Federal District showed the presence of bacterial hazards, and there is an evident need for good hygiene practices in the entire production chain to ensure consumer food safety.
\end{abstract}

Keywords: soft cheese; food hygiene; foodborne pathogens; S. aureus.

Practical Application: Comparison of the microbiological quality of industrialized and artisanal Minas fresh cheeses.

\section{Introduction}

Cheeses are a source of high-quality proteins, lipids, vitamins (A, B2 and B12) and minerals (calcium and phosphorus). The cheese matrix is a complex assembly of nutrients where protein, especially casein, hydrated with water forms networks (within the cheese matrix) in which fat globules, minerals, bacteria, lactic acid, soluble salts and peptides are all interspersed (Feeney et al., 2021).

Minas fresh cheese is a typical Brazilian cheese, being widely produced and consumed by Brazilians due to its low cost and high acceptance by consumers (Saleh et al., 2019; Souza et al., 2017). This soft white cheese is made from pasteurized cow's milk and Brazilian regulation does not permit the production of Minas fresh cheeses with raw milk, as they do not undergo a ripening process (Brasil, 2004). Because it is a nonripened cheese and has high moisture content (>55\%), Minas fresh cheese must be stored in a refrigerated temperature (not exceeding $8{ }^{\circ} \mathrm{C}$ ) and has a short shelf life (on average 15 days) (Brasil, 2004; Souza et al., 2017).

The industrialized Minas Fresh cheese is made from pasteurized milk, in a dairy industry, accompanied by the seal of the Federal Inspection Service (Dias et al., 2016). Despite the Brazilian regulation, artisanal Minas fresh cheese, commonly made with raw milk without undergoing quality control, is not inspected, and is regularly sold at Brazilian street markets and public food markets, presenting unsatisfactory hygienic-sanitary conditions during its production and conservation. It is common for these cheeses to be exhibited without refrigeration (Okura \& Marin, 2014; Wolupeck et al., 2012).

In Brazil, a large variety of artisanal cheeses exist, and they are appreciated dairy products due to their economic significance and cultural and social values. These artisanal cheeses can be produced using raw milk, and their commercialization is allowed by Brazilian regulation if scientific and technical reports confirm that the ripening time guarantees the food safety of the products (Kamimura et al., 2019; Margalho et al., 2021).

Brazilian artisanal Minas fresh cheeses have shown problems related to microbiological quality (Dias et al., 2016; Garcia et al., 2016). The concern with the quality of artisanal cheese is the health risk resulting from the use of raw milk and inadequate food safety practices during production. These factors, together with inadequate storage and sale practices in the markets, the contamination and growth of pathogens (Gould et al., 2014).

Thus, pathogenic bacteria that cause foodborne diseases such as Staphylococcus aureus, Escherichia coli, and Salmonella spp. may be present in poor quality cheeses (Freitas et al., 2013; Okura \& Marin, 2014; Guzman-Hernandez et al., 2016; Viçosa et al., 2019). Then, the aim of the present study was to evaluate the 
microbiological quality of industrial and artisanal Minas fresh cheeses commercialized in the Federal District, Brazil.

\section{Materials and methods}

\subsection{Sample collection, microbiological and molecular analysis}

A total of 40 Minas fresh cheese samples were analyzed (20 industrialized cheeses and 20 artisanal cheeses), which were collected at intervals between March 2018 and February 2020. The 20 samples of industrialized Minas fresh cheeses from different brands were collected in different supermarkets in the Federal District. The industrialized samples had a label containing the mandatory information's, a seal of the Federal Inspection Service, were in their original packaging and within the expiration date. The 20 samples of artisanal Minas fresh cheeses were collected in different public food markets in the Federal District. Samples were transported under refrigeration (4- $\left.6{ }^{\circ} \mathrm{C}\right)$ in thermal boxes containing ice packs and were tested immediately after arriving at the laboratory. All samples were analyzed in three repetitions, that is, three aliquots were removed from each package and the results were expressed as mean and standard deviation.

Twenty-five grams of each sample were aseptically homogenized in $225 \mathrm{~mL}$ of $0.1 \%(\mathrm{w} / \mathrm{v})$ peptoned water, thus obtaining the first dilution $\left(10^{-1}\right)$. The other serial decimal dilutions (up to $10^{-3}$ ) were obtained from this first dilution. For the total count of mesophilic and psychrotrophic bacteria, each dilution was plated on Plate Count agar (Acumedia, USA) and incubated at $37^{\circ} \mathrm{C}$ for $24 \mathrm{~h}$ for mesophilic bacteria and at $7^{\circ} \mathrm{C} \pm 1{ }^{\circ} \mathrm{C}$ for 7 days for psychrotrophic bacteria.

Total and thermotolerant coliforms were determined by the Most Probable Number. Each dilution of the samples was inoculated in Lauril Sulfato Triptose broth (HiMedia, USA). After $24 \mathrm{~h}$ of incubation at $37{ }^{\circ} \mathrm{C}$, an aliquot from positive cultures (determined by turbidity and gas production) was transferred, simultaneously, to tubes containing Brilliant Green Bile Lactose broth (Kasvi, Brazil) (for the confirmation of total coliforms) and Escherichia coli broth (Kasvi, Brazil) (for the confirmation of thermotolerant coliforms). The tubes were incubated at $37^{\circ} \mathrm{C}$ for $24 \mathrm{~h}$ for total coliforms and in a water bath at $45^{\circ} \mathrm{C}$ for $24 \mathrm{~h}$ for thermotolerant coliforms. Tubes with turbidity and gas production were considered positive for both tests.

For the research of Salmonella spp., the $10^{-1}$ dilution of the samples was incubated at $37^{\circ} \mathrm{C}$ for $24 \mathrm{~h}$. After incubation, aliquots were transferred to tubes containing $10 \mathrm{~mL}$ of tetrathionate broth. A loop-full of enriched broth was streaked onto the Xylose-Lysine-Deoxycholate agar (XLD) (HiMedia,
USA) and Salmonella-Shigella agar (SS) (Kasvi, Brazil) and incubated at $37^{\circ} \mathrm{C}$ for $24 \mathrm{~h}$. Presumptive Salmonella colonies in XLD and SS agars were confirmed biochemically using triple sugar iron agar (TSI) (Kasvi, Brazil) and lysine iron agar (LIA) (HiMedia, USA) slants, incubated at $37^{\circ} \mathrm{C}$ for $24 \mathrm{~h}$. Subsequently, presumptive Salmonella isolates were subjected to molecular identification using the PCR technique.

Staphylococcus aureus counts were determined by plating each dilution onto the Mannitol Salt agar (Kasvi, Brazil), with incubation at $37{ }^{\circ} \mathrm{C}$ for $48 \mathrm{~h}$. The presumptive $S$. aureus isolates were re-isolated in tubes of Mannitol Salt agar to obtain pure cultures and subjected to Gram stain method to confirm Grampositive cocci. The isolates of $S$. aureus were confirmed by molecular identification using the PCR technique.

Table 1 presents the primer for the enterotoxin $C$ gene $(\mathrm{SeC})$ used for identification of $S$. aureus and the primer for the invasion A gene $(\operatorname{Inv} A)$ used for identification of Salmonella spp.

For DNA extraction, the isolates were cultivated overnight in Mueller-Hinton broth and had their DNA extracted employing the NucleoSpin Food kit (Macherey-Nagel, Düren, Germany), as per the manufacturer's instructions. The DNA concentrations were then determined using a NanoDrop 2000 (Thermo Scientific, Pittsburgh, USA), and its integrity was confirmed by agarose gel electrophoresis. PCR was performed in a $25 \mu \mathrm{l}$ final volume reaction mixture containing: $2.5 \mu$ of PCR buffer; $0.7 \mu \mathrm{l}$ of $\mathrm{MgCl} 2 ; 1.5 \mu \mathrm{L}$ of dNTP $(2,5 \mathrm{mM}) ; 0.5 \mu \mathrm{l}$ of Taq DNA polymerase; $1.5 \mu \mathrm{L}$ of each primer forward and reverse; and $18.3 \mu \mathrm{l}$ of Milli-Q water. Theses thermal cycling reactions were conducted with Techne TC-512 thermal cycler (Bibby Scientific Inc., USA), and each PCR run included negative and reagent controls. The reagent control consisted of all PCR components except for the DNA template. The amplified DNA was separated by electrophoresis at $100 \mathrm{~V}$ for $50 \mathrm{~min}$ in $1.5 \%$ (w/v) agarose gel, stained with ethidium bromide and visualized under UV light. A 100 bp DNA ladder was used as a molecular weight marker.

\section{Results and discussion}

Tables 2 and 3 show the results of the microbiological analyzes of the cheeses analyzed in this study.

For Minas Fresh cheeses, Brazilian legislation (Brasil, 2019) does not establish limits for mesophilic and psychrotrophic bacteria counts. The International Commission on Microbiological Specifications for Foods (ICMSF, 1986) recommends a maximum count of $7.0 \mathrm{log} \mathrm{CFU} / \mathrm{g}$ of total bacteria. Results showed that of the 40 samples analyzed in this study, 3 samples $(4.0 \%)$ of industrialized cheeses and 7 samples (17.5\%) of artisanal cheeses presented values above $7.0 \mathrm{log} \mathrm{CFU} / \mathrm{g}$ for mesophilic bacteria count.

Table 1. Sequence of primers and size of products amplified in PCR for identification of $\operatorname{SeC}$ and invA genes.

\begin{tabular}{ccc}
\hline Primer & Sequence 5' 3 $^{\prime}$ & Amplified product \\
seC foward & TTTTACACCCAACGTATTAGCAGA & S01 bp \\
se reverse & TCCCATTATCAAAGTGGTTTCC & 298 bp \\
invA foward & CTCGCCTTTGCTGGTTTTAG & Salmonella spp. \\
in $A$ reverse & CTCGCCTTTGCTGGTTTTAG & \\
\hline
\end{tabular}


Table 2. Microbiological results of industrialized Minas fresh cheese samples.

\begin{tabular}{|c|c|c|c|c|c|c|}
\hline Samples & $\begin{array}{l}\text { Mesophilic bacteria } \\
\quad(\log \text { CFU/g) }\end{array}$ & $\begin{array}{c}\text { Psychrotrophic } \\
\text { bacteria }(\log \text { CFU/g) }\end{array}$ & $\begin{array}{l}\text { Total coliforms } \\
(\log \text { MPN/g) }\end{array}$ & $\begin{array}{c}\text { Thermotolerant } \\
\text { coliforms } \\
(\log \text { MPN/g) }\end{array}$ & Salmonella spp. & $\begin{array}{c}\text { S. aureus } \\
(\log \mathrm{CFU} / \mathrm{g})\end{array}$ \\
\hline 1 & $5.6 \pm 0.60$ & $5.9 \pm 0.21$ & $3.1 \pm 0.00$ & $3.1 \pm 0.00$ & Negative & ND \\
\hline 2 & $4.7 \pm 0.36$ & $4.0 \pm 0.24$ & $0.8 \pm 0.26$ & $0.5 \pm 0.00$ & Negative & ND \\
\hline 3 & $5.1 \pm 0.07$ & $6.6 \pm 0.13$ & $3.1 \pm 0.00$ & $2.1 \pm 0.86$ & Negative & $3.6 \pm 0.25$ \\
\hline 4 & $6.8 \pm 0.37$ & $7.5 \pm 0.23$ & $3.1 \pm 0.00$ & $2.5 \pm 0.58$ & Negative & $2.6 \pm 0.28$ \\
\hline 5 & $6.8 \pm 1.54$ & $7.2 \pm 0.34$ & $1.1 \pm 0.34$ & $0.5 \pm 0.00$ & Negative & ND \\
\hline 6 & $7.1 \pm 0.22$ & $7.9 \pm 0.27$ & $3.1 \pm 0.00$ & $0.5 \pm 0.00$ & Negative & $2.5 \pm 0.70$ \\
\hline 7 & $6.1 \pm 1.16$ & $6.9 \pm 0.16$ & $1.0 \pm 0.19$ & $0.6 \pm 0.18$ & Negative & ND \\
\hline 8 & $5.3 \pm 0.18$ & $6.7 \pm 0.07$ & $0.5 \pm 0.05$ & $0.5 \pm 0.00$ & Negative & $\mathrm{ND}$ \\
\hline 9 & $7.3 \pm 0.47$ & $7.8 \pm 0.10$ & $0.5 \pm 0.00$ & $0.5 \pm 0.00$ & Negative & $\mathrm{ND}$ \\
\hline 10 & $5.3 \pm 0.55$ & $7.5 \pm 0.25$ & $1.9 \pm 0.67$ & $0.7 \pm 0.23$ & Negative & ND \\
\hline 11 & $5.3 \pm 1.28$ & $7.1 \pm 0.15$ & $3.1 \pm 0.00$ & $1.8 \pm 1.12$ & Negative & ND \\
\hline 12 & $6.9 \pm 0.03$ & $4.1 \pm 0.21$ & $3.1 \pm 0.00$ & $2.2 \pm 0.43$ & Negative & $2.1 \pm 0.89$ \\
\hline 13 & $6.6 \pm 0.06$ & $6.1 \pm 0.17$ & $3.1 \pm 0.00$ & $2.8 \pm 0.33$ & Negative & $3.8 \pm 0.48$ \\
\hline 14 & $7.1 \pm 0.40$ & $5.9 \pm 0.21$ & $3.1 \pm 0.00$ & $3.1 \pm 0.00$ & Negative & ND \\
\hline 15 & $5.5 \pm 0.49$ & $3.3 \pm 0.42$ & $3.1 \pm 0.00$ & $3.1 \pm 0.00$ & Negative & ND \\
\hline 16 & $7.8 \pm 0.16$ & $6.7 \pm 0.05$ & $3.1 \pm 0.00$ & $0.5 \pm 0.00$ & Negative & $3.0 \pm 0.00$ \\
\hline 17 & $6.3 \pm 0.09$ & $6.7 \pm 0.01$ & $3.1 \pm 0.00$ & $1.0 \pm 1.34$ & Negative & ND \\
\hline 18 & $6.6 \pm 0.12$ & $7.4 \pm 0.30$ & $2.6 \pm 0.38$ & ND & Negative & $\mathrm{ND}$ \\
\hline 19 & $5.5 \pm 0.71$ & $4.5 \pm 0.12$ & $1.9 \pm 0.96$ & ND & Negative & ND \\
\hline 20 & $6.9 \pm 0.55$ & $6.3 \pm 0.44$ & $3.1 \pm 0.00$ & $2.9 \pm 0.34$ & Negative & ND \\
\hline
\end{tabular}

Results are reported as means \pm standard deviation of triplicate measurements; ND: not detected.

Studies have reported high counts of mesophilic bacteria in both artisanal and industrialized Minas fresh cheeses from different regions of Brazil. Funck et al. (2015) reported high counts of mesophilic bacteria (7.1-7.3 log CFU/g) in artisanal cheeses from the Northwestern region of Rio Grande do Sul. Garcia et al. (2016) also reported high counts of mesophilic bacteria in 78\% of artisanal cheese samples, produced and marketed in Montes Claros region, Minas Gerais. And Wolupeck et al. (2012) presented results of 7,5 to 9,0 log CFU/g for the mesophilic aerobic counts in industrialized brands of Minas Fresh cheeses marketed in the city of Curitiba (Paraná). The high count of mesophilic bacteria in dairy products indicates poor hygiene of raw materials and deficiencies in cheese processing and storage (Funck et al., 2015; Wolupeck et al., 2012).

For psychrotrophic bacteria, 7 samples (17.5\%) of industrialized cheeses and 5 samples (12.5\%) of artisanal cheeses presented values above $7.0 \mathrm{log} \mathrm{CFU} / \mathrm{g}$. The control of psychrotrophic microorganisms is of great importance for the dairy industry, as this group of microorganisms develops in refrigeration temperatures. High counts of psychrotrophic bacteria are responsible for the deterioration of cheeses, as they produce enzymes that hydrolyze proteins and lipids, reducing their shelf life. In addition, the high count of this group of microorganisms can be attributed to storage at inappropriate temperatures (Oliveira et al., 2015; Santana et al., 2020).

Brazilian legislation (Brasil, 2019) does not establish limits for total coliforms in Minas Fresh cheeses, however, the legislation which approves the Technical Regulations for the Identity and Quality of Dairy Products (Brasil, 1996), establishes a limit of $3.0 \log \mathrm{MPN} / \mathrm{g}$. Of the 40 samples analyzed in this study, 12 industrialized cheeses (30\%) and 12 artisanal cheeses (30\%) had an enumeration of total coliforms higher than $3.0 \log \mathrm{MPN} / \mathrm{g}$.

Dias et al. (2016) observed that all samples of industrialized cheeses ( 5 samples) and artisanal cheeses ( 5 samples) marketed in the South of Goiás showed total coliforms values higher than $3.0 \log \mathrm{MPN} / \mathrm{g}$. Souza et al. (2017) reported an enumeration of total coliforms higher than $3.0 \log$ MPN/g in 77,4\% of Minas fresh cheeses samples marketed in Minas Gerais (Zona da Mata Mineira). These microorganisms are important indicators of the hygiene conditions of the production processes, as they are generally environmental contaminants and are easily destroyed by the pasteurization process of milk (Dias et al., 2016; Garcia et al., 2016).

The limit for thermotolerant coliforms in Minas Fresh cheeses is $3.0 \log \mathrm{NMP} / \mathrm{g}$ (Brasil, 2019). The results showed that 3 industrialized cheeses $(7.5 \%)$ and 6 artisanal cheeses (15\%) presented values above $3.0 \log \mathrm{NMP} / \mathrm{g}$, and therefore were unfit for consumption. Thermotolerant coliforms is used as an indicator of direct or indirect fecal contamination of foods ( $E$. coli represents $90 \%$ of the bacteria in this group), and therefore the possible presence of enteric pathogens. In cheese its presence indicates poor hygiene conditions during processing or postprocessing contamination (Okura \& Marin, 2014).

Several studies have reported a high frequency of Minas fresh cheeses unfit for consumption due to high number of thermotolerant coliforms. Apolinário et al. (2014) reported that of the 31 samples of industrialized Minas fresh cheeses produced in Minas Gerais, 17 samples (54.8\%) showed values above the limit allowed for thermotolerant coliforms. Saleh et al. 
Table 3. Microbiological results of artisanal Minas fresh cheese samples.

\begin{tabular}{|c|c|c|c|c|c|c|}
\hline Samples & $\begin{array}{l}\text { Mesophilic bacteria } \\
\quad(\log \text { CFU/g) }\end{array}$ & $\begin{array}{c}\text { Psychrotrophic } \\
\text { bacteria }(\log \text { CFU/g) }\end{array}$ & $\begin{array}{l}\text { Total coliforms } \\
(\log \text { MPN/g) }\end{array}$ & $\begin{array}{c}\text { Thermotolerant } \\
\text { coliforms } \\
(\log \text { MPN/g) }\end{array}$ & Salmonella spp. & $\begin{array}{c}\text { S. aureus } \\
(\log \mathrm{CFU} / \mathrm{g})\end{array}$ \\
\hline 1 & $7.8 \pm 0.08$ & $7.9 \pm 0.37$ & $2.5 \pm 0.48$ & $0.6 \pm 0.15$ & Negative & $5.3 \pm 0.02$ \\
\hline 2 & $7.5 \pm 0.34$ & $7.3 \pm 0.01$ & $1.4 \pm 0.15$ & $1.1 \pm 0.46$ & Negative & $4.9 \pm 0.07$ \\
\hline 3 & $7.0 \pm 0.05$ & $6.4 \pm 0.05$ & $0.6 \pm 0.14$ & $0.6 \pm 0.00$ & Negative & $6.3 \pm 0.02$ \\
\hline 4 & $6.1 \pm 0.04$ & $5.6 \pm 0.16$ & $1.1 \pm 0.13$ & $0.7 \pm 0.14$ & Negative & $3.6 \pm 0.18$ \\
\hline 5 & $4.9 \pm 0.30$ & $5.8 \pm 0.17$ & $1.1 \pm 0.00$ & $0.5 \pm 0.00$ & Negative & $3.0 \pm 0.04$ \\
\hline 6 & $7.5 \pm 0.09$ & $7.6 \pm 0.06$ & $0.6 \pm 0.18$ & ND & Negative & $5.8 \pm 0.49$ \\
\hline 7 & $5.6 \pm 0.46$ & $7.2 \pm 0.04$ & $3.1 \pm 0.01$ & $3.1 \pm 0.01$ & Positive & $2.9 \pm 0.17$ \\
\hline 8 & $6.4 \pm 0.04$ & $7.5 \pm 0.09$ & $2.0 \pm 0.93$ & $0.9 \pm 0.48$ & Negative & $4.1 \pm 0.08$ \\
\hline 9 & $8.0 \pm 0.14$ & $5.2 \pm 0.04$ & $3.1 \pm 0.01$ & $1.1 \pm 0.29$ & Negative & $3.9 \pm 0.01$ \\
\hline 10 & $6.2 \pm 0.38$ & $5.9 \pm 0.50$ & $3.1 \pm 0.00$ & $2.8 \pm 0.38$ & Negative & $4.9 \pm 0.68$ \\
\hline 11 & $5.8 \pm 0.07$ & $6.0 \pm 0.03$ & $3.1 \pm 0.00$ & $2.5 \pm 0.86$ & Negative & $5.1 \pm 0.12$ \\
\hline 12 & $6.5 \pm 0.60$ & $6.8 \pm 0.25$ & $3.1 \pm 0.00$ & $1.3 \pm 0.07$ & Negative & $3.8 \pm 0.86$ \\
\hline 13 & $7.1 \pm 0.05$ & $5.7 \pm 0.13$ & $3.1 \pm 0.00$ & $3.1 \pm 0.00$ & Negative & $4.8 \pm 0.15$ \\
\hline 14 & $6.2 \pm 0.26$ & $5.0 \pm 0.15$ & $3.1 \pm 0.00$ & $3.1 \pm 0.00$ & Negative & $5.0 \pm 0.01$ \\
\hline 15 & $6.3 \pm 0.39$ & $4.3 \pm 0.43$ & $3.1 \pm 0.00$ & $1.9 \pm 0.05$ & Negative & $4.8 \pm 0.13$ \\
\hline 16 & $7.2 \pm 0.53$ & $4.1 \pm 0.20$ & $3.1 \pm 0.00$ & $3.1 \pm 0.00$ & Negative & $4.9 \pm 0.21$ \\
\hline 17 & $4.5 \pm 0.15$ & $3.1 \pm 0.09$ & $3.1 \pm 0.00$ & $3.1 \pm 0.00$ & Negative & $3.6 \pm 0.49$ \\
\hline 18 & $6.9 \pm 0.07$ & $5.0 \pm 0.75$ & $3.1 \pm 0.00$ & $2.5 \pm 0.59$ & Negative & $3.4 \pm 0.17$ \\
\hline 19 & $6.1 \pm 0.09$ & $6.1 \pm 0.06$ & $3.1 \pm 0.00$ & $3.1 \pm 0.00$ & Negative & $4.0 \pm 0.90$ \\
\hline 20 & $5.2 \pm 0.26$ & $4.1 \pm 0.21$ & $2.7 \pm 0.00$ & $2.5 \pm 0.16$ & Negative & $4.0 \pm 0.21$ \\
\hline
\end{tabular}

Results are reported as means \pm standard deviation of triplicate measurements; ND: not detected.

(2019), reported that of the 19 industrialized samples sold in supermarkets in the city of Duque de Caxias (Rio de Janeiro), 10 samples $(52.6 \%)$ presented thermotolerant coliforms counts above $3.0 \log \mathrm{NMP} / \mathrm{g}$. And Garcia et al. (2016), reported that 17 samples (94.4\%) of artisanal cheeses produced and marketed in Montes Claros (Minas Gerais), were unfit for consumption because they exceed limits allowed for thermotolerant coliforms.

According to Perrin et al. (2015), pathogenic strains such as Shiga-toxin producing Escherichia coli (STEC) can survive during cheese processing, especially in soft cheeses produced with raw milk. The authors reported that impact of the preharvest interventions (vaccination, use of probiotics, antimicrobials, milk farm sorting) reduced $76-98 \%$ the risk of cow carrying STEC and of the STEC concentration in feces. Thus, preharvest treatments need to be applied to reduce the microbial risk in soft cheeses made with raw milk.

Storage temperature is another factor that affects the development of E. coli in cheeses. Kim et al. (2014) developed kinetic models to predict the growth of pathogenic E. coli in cheeses during storage at changing temperatures. At $4^{\circ} \mathrm{C}$, E. coli growth was not observed in any cheeses, however, E. coli growth was observed at $10{ }^{\circ} \mathrm{C}$ in counts of 6.3 to $8.6 \mathrm{log} \mathrm{CFU} / \mathrm{g}$ after 13 days of storage. Lima et al. (2015) evaluated the viability of pathogenic E. coli in Minas fresh cheeses stored at $8{ }^{\circ} \mathrm{C}$. There was an increase in the counts of E. coli during storage at $8{ }^{\circ} \mathrm{C}$. The cheese processing did not eliminate microorganisms and the storage temperature recommended by Brazilian legislation did not eliminate bacterial growth, keeping the risk for the population. These results reinforce the attention to the quality of the milk to ensure the safety of final products.
Brazilian legislation (Brasil, 2019) does not allow the presence of Salmonella spp. in cheeses. The results showed that only 1 artisanal cheese $(2,5 \%)$ presented Salmonella spp., and this cheese was already unfit for consumption due to the excess of thermotolerant coliforms. According to Chávez-Martínez et al. (2019), the pasteurization of milk is one of the most effective measures to prevent microbial contamination and the presence of Salmonella spp. in cheeses is mainly a result of insufficient pasteurization. Other studies have reported the presence of Salmonella in artisanal cheeses or in cheeses made from raw milk. Chávez-Martínez et al. (2019) found Salmonella spp. in $8.9 \%$ of cheese samples commercialized in Mexico and 5 samples were fresh cheeses made with raw milk. Martínez et al. (2020) reported the presence of Salmonella spp. in $17.9 \%$ of artisanal fresh cheeses commercialized in Cuba. And GuzmanHernandez et al. (2016) reported that of the 52 samples of Mexican unpasteurized fresh cheeses, 11 samples (21\%) were contaminated with Salmonella spp.

The limit for S. aureus in Minas fresh cheeses is 3.0 $\log \mathrm{NMP} / \mathrm{g}$ (Brasil, 2019). The results showed that of the 40 samples analyzed, 3 industrialized cheeses (7.5\%) and all 20 artisanal cheeses (50\%) presented $S$. aureus counts above $3.0 \log \mathrm{NMP} / \mathrm{g}$. Although some samples of industrialized cheeses were contaminated with $S$. aureus in counts above the allowed, it is remarkable the results obtained for the samples of artisanal cheeses, where all the samples were unfit for consumption due to the excess of S. aureus. Dias et al. (2016) and Garcia et al. (2016) reported similar results and all samples of artisanal Minas fresh cheeses presented counts of $S$. aureus above $3.0 \log \mathrm{NMP} / \mathrm{g}$. Martínez et al. (2020) evaluated artisanal fresh cheeses in Cuba and reported that $51.6 \%$ of samples presented counts of S. aureus above 3.0 
$\log \mathrm{NMP} / \mathrm{g}$. For industrialized Minas fresh cheese samples, Apolinário et al. (2014) and Souza et al. (2017) reported better results with 5 samples (16\%) and 16 samples (32\%) unfit for consumption due to the high counts of $S$. aureus, respectively.

The high S. aureus count in artisanal Minas fresh cheeses suggests the use of raw milk from infected animals (mastitis). $S$. aureus presence in cheeses have been linked to the use of unpasteurized milk or to contamination due to improper handling. Most staphylococcal intoxications are caused by contamination from the food-handler during food processing. However, cows thar suffer from subclinical mastitis are accepted as alternative reservoirs of enterotoxin producing $S$. aureus, which contaminate the dairy production chain (Kümmel et al., 2016). The genotype $\mathrm{B}$ of $S$. aureus is associated with bovine mastitis and is known for its high prevalence within the herd (Cremonesi et al., 2015), being able to produce staphylococcal enterotoxins and reported as an important source of contamination by S. aureus from Swiss cheeses from raw milk (Hummerjohann et al., 2014).

Furthermore, the fact that $S$. aureus strains can adhere to the surface of utensils used during the manufacturing process, besides their ability to be strong biofilm producers, increases their persistence in the dairy production chain (Silva et al., 2017). Ingestion of enterotoxins produced by S. aureus in food can result in staphylococcal food intoxication, and some outbreaks linked to consumption of raw milk cheeses and artisanal cheeses have been reported (Johler et al., 2015).

S. aureus intoxication is characterized by nausea, vomiting and diarrhea, and it is linked to consumption of food contaminated by one or more preformed heat-resistant staphylococcal enterotoxins (ses) that are produced when the bacterial counts reach 4-5 log $\mathrm{CFU} / \mathrm{g}$ (Hummerjohann et al., 2014; Kümmel et al., 2016). In our study 13 samples $(32,5 \%)$ of artisanal cheeses presented $S$. aureus with counts higher than $4 \log$ CFU/g. Martínez et al. (2020), reported that $51.6 \%$ of the cheese samples were contaminated with $S$. aureus with concentration higher than $4 \log \mathrm{CFU} / \mathrm{g}$.

Staphylococcal enterotoxins (ses) are a group of thermostable toxins that are resistant to gastric $\mathrm{pH}$ and gastrointestinal proteases (Hummerjohann et al., 2014). Thus, once ses are formed in food production, these highly stable toxins will not be destroyed by common hygienic measures and pose a health risk for the consumers (Kümmel et al., 2016). Enterotoxins A (seA), B (seB), C (seC), D (seD) and E (seE) are the most common toxins observed in association with staphylococcal food intoxication (Hummerjohann et al., 2014).

S. aureus were confirmed in our study by the molecular detection of gene $s e C$ and all samples tested presented this gene, indicating the potential of these strains to produce enterotoxins. Martínez et al. (2020) also confirmed the occurrence of staphylococcal enterotoxin genes by PCR in samples of fresh cheese marketed in Cuba.

Gallegos-Acevedo et al. (2019) reported a high number of mesophilic and psychrotrophic bacteria, total coliforms, Staphylococcus bacteria and molds in artisanal Ranchero cheeses made with raw milk and obtained from local producers in Mexico. Sanitation deficiencies in the production of artisanal
Ranchero cheese were evident, which may translate into being a potential consumers health risk factor.

Silva et al. (2017) reported that Minas fresh cheeses can be handmade on small farms with raw milk, without proper hygiene control, resulting in a product with high levels of bacterial contamination, including $S$. aureus and coliforms. Frau et al. (2021) described that most of the cheese manufactured and sold in the in the north of Argentina is artisanal fresh cheese and is usually made by farmers on a small scale in their farmhouse, using traditional techniques. The final product has a high moisture content (50 to $65 \%$ ), a low pH (4.1 to 4.5 ), and a short shelf life $(<30 \mathrm{~d})$. These products have gained popularity due to the increased interest of consumers in the tradition of cheesemaking. According to Choi et al. (2016) cheese related foodborne illnesses have been generally linked to soft cheese or cheese made from raw or unpasteurized milk, but rarely in hard cheese. Hence, manufacturing and storage process should be controlled appropriately to prevent foodborne illness by these cheeses.

\section{Conclusions}

The results showed that $65 \%$ of Minas fresh cheeses (26/40) were unfit for consumption according to Brazilian legislation. The industrialized cheeses showed better microbiological quality than the artisanal cheeses, highlighting the importance of inspection in the production chain of these cheeses. All 20 samples (50\%) of artisanal cheeses were not approved for consumption due to the high $S$. aureus counts. Strains of S. aureus isolated from these cheeses had confirmation of the $\mathrm{seC}$ gene, indicating the potential of these strains to produce enterotoxins. When the bacterial counts reach 4-5 log CFU/g there is a potential risk of toxin production in food and the results showed that most samples of artisanal cheeses (13/20) presented S. aureus with counts higher than $4 \log \mathrm{CFU} / \mathrm{g}$. Although it is illegal in Brazil, there is production of artisanal Minas fresh cheeses from raw milk without official sanitary inspection. These cheeses may also have been contaminated in processing, in addition to being kept at room temperature when commercialized. Thus, there is a clear need for good manufacturing practices throughout the Minas fresh cheese production chain, to reduce health risks and ensure consumer food safety.

\section{Acknowledgements}

This study was financed by UnB (Edital DPG n. 0004/2021) and by Coordenação de Aperfeiçoamento de Pessoal de Nível Superior, Brasil (CAPES - Finance Code 001)

\section{References}

Apolinário, T. C. C., Santos, G. S., \& Lavorato, J. A. A. (2014). Avaliação da qualidade microbiológica do queijo minas frescal produzido por laticínios do estado de Minas Gerais. Revista do Instituto de Latícinios Cândido Tostes, 69(6), 433-442. http://dx.doi.org/10.14295/22386416.v69i6.290.

Brasil, Ministério da Agricultura, Pecuária e Abastecimento. (2004). Instrução Normativa ${ }^{\circ} 4$ de 01 de março de 2004. Regulamento 
técnico para fixação de identidade e qualidade do queijo minas frescal. Diário Oficial da República Federativa do Brasil, Brasília.

Brasil, Ministério da Agricultura, Pecuária e Abastecimento. (1996). Portaria n ${ }^{\circ} 146$ de 07 de março de 1996. Aprova os Regulamentos Técnicos de Identidade e Qualidade dos Produtos Lácteos. Diário Oficial da República Federativa do Brasil, Brasília.

Brasil, Ministério da Saúde, Agência Nacional de Vigilância Sanitária, Diretoria Colegiada. (2019). Instrução Normativa $n^{\circ}$ 60, de 23 de dezembro de 2019. Estabelece as listas de padrões microbiológicos para alimentos. Diário Oficial da República Federativa do Brasil, Brasília.

Chávez-Martínez, A., Paredes-Montoya, P., Rentería-Monterrubio, A. L., Corral-Luna, A., Lechuga-Valles, R., Dominguez-Viveros, J., Sánchez-Vega, R., \& Santellano-Estrada, E. (2019). Microbial quality and prevalence of foodborne pathogens of cheeses commercialized at different retail points in Mexico. Food Science and Technology, 39(Suppl. 2), 703-710. http://dx.doi.org/10.1590/fst.30618.

Choi, K., Lee, H., Lee, S., Kim, S., \& Yoon, Y. (2016). Cheese microbial risk assessments - a review. Asian-Australasian Journal of Animal Sciences, 29(3), 307-314. http://dx.doi.org/10.5713/ajas.15.0332. PMid:26950859.

Cremonesi, P., Pozzi, F., Raschetti, M., Bignoli, G., Capra, E., Graber, H. U., Vezzoli, F., Piccinini, R., Bertasi, B., Biffani, S., Castiglioni, B., \& Luini, M. (2015). Genomic characteristics of Staphylococcus aureus strains associated with high within-herd prevalence of intramammary infections in dairy cows. Journal of Dairy Science, 98(10), 6828-6838. http://dx.doi.org/10.3168/jds.2014-9074. PMid:26233457.

Dias, B. F., Ferreira, S. M., Carvalho, V. S., \& Soares, D. S. B. (2016). Qualidade microbiológica e físico-química de queijo minas frescal artesanal e industrial. Revista de Agricultura Neotropical, 3(3), 57-64. http://dx.doi.org/10.32404/rean.v3i3.1211.

Feeney, E. L., Prabin, L., \& Sheehan, J. J. (2021). The cheese matrix: understanding the impact of cheese structure on aspects of cardiovascular health - a food science and a human nutrition perspective. International Journal of Dairy Technology, 0, 1-15.

Frau, F., Carate, J. N. L., Salinas, F., \& Pece, N. (2021). Effect of vacuum packaging on artisanal goat cheeses during refrigerated storage. Food Science and Technology, 41(2), 295-303. http://dx.doi.org/10.1590/ fst.36719.

Freitas, R., Brito, M. A. V. P., Nero, L. A., \& Carvalho, A. F. (2013). Microbiological safety of Minas Frescal cheese (MFC) and tracking the contamination of Escherichia coli and Staphylococcus aureus in MFC processing. Foodborne Pathogens and Disease, 10(11), 951-955. http://dx.doi.org/10.1089/fpd.2013.1525. PMid:23909773.

Funck, G. D., Hermanns, G., Vicenzi, R., Schmidt, J. T., Richards, N. S. P. S., Silva, W. P., \& Fiorentini, A. M. (2015). Microbiological and physicochemical characterization of the raw milk and the colonial type cheese from the Northwestern Frontier region of Rio Grande do Sul, Brazil. Revista do Instituto Adolfo Lutz, 74(3), 247-257.

Gallegos-Acevedo, M.-A., Chávez-Martínez, A., Corral-Luna, A., Rentería-Monterrubio, A.-L., Burrola-Barraza, M. E., Lechuga-Valles, R., Dominguez-Viveros, J., Castillo-González, A.-R., \& SánchezVega, R. (2019). Microbial characterization and diversity of artisanal Ranchero cheese with emphasis in Lactococcus strains. Food Science and Technology, 39(1), 143-148. http://dx.doi.org/10.1590/fst.28217.

Garcia, J. K. S., Prates, R. P., Farias, P. K. S., Gonçalves, S. F., \& Souza, C. N. (2016). Qualidade microbiológica de queijos frescos artesanais comercializados na região do norte de Minas Gerais. Caderno de Ciências Agrárias, 8(2), 58-65.

Gould, L. H., Mungai, E., \& Behravesh, C. B. (2014). Outbreaks attributed to cheese: differences between outbreaks caused by unpasteurized and pasteurized dairy products, United States, 1998-2011. Foodborne
Pathogens and Disease, 11(7), 545-551. http://dx.doi.org/10.1089/ fpd.2013.1650. PMid:24750119.

Guzman-Hernandez, R., Contreras-Rodriguez, A., Hernandez-Velez, R., Perez-Martinez, I., Lopez-Merino, A., Zaidi, M. B., \& Estrada-Garcia, T. (2016). Mexican unpasteurized fresh cheeses are contaminated with Salmonella spp., non-O157 Shiga toxin producing Escherichia coli and potential uropathogenic E. coli strains: a public health risk. International Journal of Food Microbiology, 237, 10-16. http://dx.doi. org/10.1016/j.ijfoodmicro.2016.08.018. PMid:27541977.

Hummerjohann, J., Naskova, J., Baumgartner, A., \& Graber, H. U. (2014). Enterotoxin-producing Staphylococcus aureus genotype B as a major contaminant in Swiss raw milk cheese. Journal of Dairy Science, 97(3), 1305-1312. http://dx.doi.org/10.3168/jds.2013-7643. PMid:24440268.

International Commission on Microbiological Specifications for Foods - ICMSF. (1986). Sampling for microbiological analysis: principles and specific applications. Toronto: International Commission on Microbiological Specifications for Foods Publisher.

Johler, S., Weder, D., Bridy, C., Huguenin, M. C., Robert, L., Hummerjohann, J., \& Stephan, R. (2015). Outbreak of staphylococcal food poisoning among children and staff at a Swiss boarding school due to soft cheese made from raw milk. Journal of Dairy Science, 98(5), 29442948. http://dx.doi.org/10.3168/jds.2014-9123. PMid:25726108.

Kamimura, B. A., Magnani, M., Luciano, W. A., Campagnollo, F. B., Pimentel, T. C., Alvarenga, V. O., Pelegrino, B. O., Cruz, A. G., \& Sant'Ana, A. S. (2019). Brazilian artisanal cheeses: an overview of their characteristics, main types and regulatory aspects. Comprehensive Reviews in Food Science and Food Safety, 18(5), 1636-1657. http:// dx.doi.org/10.1111/1541-4337.12486. PMid:33336917.

Kim, K., Lee, H., Gwak, E., \& Yoon, Y. (2014). Kinetic behavior of Escherichia coli on various cheeses under constant and dynamic temperature. Asian-Australasian Journal of Animal Sciences, 27(7), 1013-1018. http://dx.doi.org/10.5713/ajas.2013.13579. PMid:25050044.

Kümmel, J., Stessl, B., Gonano, M., Walcher, G., Bereuter, O., Fricker, M., Grunert, T., Wagner, M., \& Ehling-Schulz, M. (2016). Staphylococcus aureus entrance into the dairy chain: Tracking S. aureus from dairy cow to cheese. Frontiers in Microbiology, 7, 1-11.

Lima, P. G., Silva, T. M., Esper, L. M. R., Gonzalez, A. G. M., \& Franco, R. M. (2015). Viabilidade de Escherichia coli O153:H25, O113:H21 e O111:H8 (STEC não-O157) produtoras de toxina Shiga em queijo minas frescal. Ciência Rural, 45(1), 52-57. http://dx.doi. org/10.1590/0103-8478cr20131678.

Margalho, L. P., Kamimura, B. A., Pimentel, T. C., Balthazar, C. F., Araujo, J. V. A., Silva, R., Conte-Junior, C. A., Raices, R. S. L., Cruz, A. G., \& Sant'Ana, A. S. (2021). A large survey of the fatty acid profile and gross composition of Brazilian artisanal cheeses. Journal of Food Composition and Analysis, 101, 103955. http://dx.doi.org/10.1016/j. jfca.2021.103955.

Martínez, A., Montes de Oca, N., Armenteros, M., Uffo, O., Riverón, Y., González, D., Remón, D., Benone Paes, S., Adrião, M., Farías de Andrade, S., \& Villoch, A. (2020). Identification of bacterial hazards in the production of artisan fresh cheese in Cuba. The Journal of Dairy Research, 87(2), 263-265. http://dx.doi.org/10.1017/ S0022029920000217. PMid:32431250.

Okura, M. H., \& Marin, J. M. (2014). Survey of Minas frescal cheese from Southwest Minas Gerais for virulence factors and antimicrobial resistance in Escherichia coli isolates. Ciência Rural, 44(8), 1506-1511. http://dx.doi.org/10.1590/0103-8478cr20131237.

Oliveira, G. B. O., Favarin, L., Luchese, R. H., \& McIntosh, D. (2015). Psychrotrophic bacteria in milk: How much do we really know? 
Brazilian Journal of Microbiology, 46(2), 313-321. http://dx.doi. org/10.1590/S1517-838246220130963. PMid:26273245.

Perrin, F., Tenenhaus-Aziza, F., Michel, V., Miszczycha, S., Bel, N., \& Sanaa, M. (2015). Quantitative risk assessment of hemolytic and uremic syndrome linked to O157:H7 and nonO157:H7 shiga-toxin producing Escherichia coli strains in raw milk soft cheeses. Risk Analisys, 35(1), 109-128. http://dx.doi.org/10.1111/risa.12267. PMid:25156259.

Saleh, M. M., Vargas, D. F. M., Bastos, I. S., Baptista, R. F., Costa, A. P., Kasnowski, M. C., \& Franco, R. M. (2019). Avaliação microbiológica de queijo Minas Frescal comercializado no município de Duque de Caxias/RJ. Revista Brasileira de Higiene e Sanidade Animal, 13(1), 78-88.

Santana, E. H. W., Luiz, L. L., Pasquim, P. S., Pinto, L. F. B., Pereira, F. A. B., Gasparini, G. B. F. B., Lorenzetti, E., Bruzaroski, S. R., \& Eleodoro, J. I. (2020). Psychrotrophic microorganisms in raw milk and the cheese quality. Research, Social Development, 9(9), e127997217. http://dx.doi.org/10.33448/rsd-v9i9.7217.

Silva, N. C. C., Bonsaglia, E. C. R., \& Fernandes Júnior, A. (2017). Biofilm production by Staphylococcus Sp on stainless steel chips in contact with Brazilian Minas Cheese homogenates and Bhi Broth under different extrinsic factors. Journal of Microbiology, Biotechnology and Food Sciences, 7(2), 190-192. http://dx.doi.org/10.15414/ jmbfs.2017.7.2.190-192.

Souza, I. A., Giovannetti, A. C. S., Santos, L. G. F., Gandra, S. O. S., Martins, M. L., \& Ramos, A. L. S. (2017). Qualidade microbiológica de queijo Minas frescal comercializado na Zona da Mata Mineira. Revista do Instituto de Latícinios Cândido Tostes, 72(3), 152-162. http://dx.doi.org/10.14295/2238-6416.v72i3.598.

Viçosa, G. N., Botelho, C. V., Botta, C., Bertolino, M., Carvalho, A. F., Nero, L. A., \& Cocolina, L. (2019). Impact of co-cultivation with Enterococcus faecalis overgrowth, enterotoxin production and gene expression of Staphylococcus aureus in broth and fresh cheeses. International Journal of Food Microbiology, 308, 1-8.

Wolupeck, H. L., Raksa, H. C., Rossa, L. S., Biasi, R., \& Macedo, R. E. F. (2012). Evolução da qualidade microbiológica de queijo Minas frescal comercializado em Curitiba (PR) no intervalo de 10 anos (1999 e 2009). Revista Acadêmica: Ciências Agrárias e Ambientais, 10(3), 243-252. http://dx.doi.org/10.7213/academica.7707. 